\title{
Research on Inheritance of Folk Belief Culture and Reconstruction of Rural Public Space
}

\author{
Wenxia Weng \\ Wuhan University of Science and Technology \\ Wuhan, China 430065
}

\author{
Fang Xie \\ Wuhan University of Science and Technology \\ Wuhan, China 430065
}

\author{
Lei Zhu \\ Wuhan University of Science and Technology \\ Wuhan, China 430065
}

\begin{abstract}
Through exploring far-reaching influence of village public space on construction of village culture and social order and its significance and deeply analyzing and contrasting concrete transformation of village public space in urban-rural integration process, the research finds out traditional folk belief creates an important carrier and public space for transmission of politics, economy and civilization, making for nourishing village public spirit and reconstructing "cultural fundamental order" of the village. This paper proposes it is an effective impetus to objectively look upon folk belief, extract its elements and reconstruct new rural public space based on modern aesthetic and function needs for activation of rural culture and construction of new countryside with regional features.
\end{abstract}

Keywords—folk belief; public space; rural culture

\section{INTRODUCTION}

Under the strike of "modernity" on Chinese traditional culture, village temples, memorial temples and other public space formed on the basis of folk belief and temple fairs, street market and ceremonies of weddings and funerals in traditional villages gradually disappear. Collective cultural activities with regional features carried out in such public space, like local opera, beating the drum and lion dancing, languor. Traditional public space is replaced by modern public cultural places. In recent years, under the background of new rural construction, the government makes great efforts to build many public cultural places, like countryside library, cultural auditorium and cultural square. However, this kind of cultural construction project propelled by a brute force obtains little actual achievement. Cultural palaces stay in an idle state all year round and most of villagers' cultural activities tend to turn to personal (family) space. According to the investigation, watching TV and playing cards become most peasants' favorite entertainment activities in their spare time away from labor work. Personal-centered cultural activity form occupies peasants' daily cultural life space, influencing construction of rural cultural value and social order and accelerating "semiacquaintance socialization" of village.

In the transition phase when traditional public space disappears little by little and modern cultural public space is not activated yet, traditional regional culture shrinks continuously with increasingly highlighted problems, like rural hollowing, interpersonal relationship atomization and disintegration of village public morality. This kind of ignorance on traditional culture and fading away of public space reflects cultural non-confidence and certainly will lead to missing of villagers' sense of belonging and recognition of cultural identity. Therefore, it is of great significance for China's new rural construction and development to explore how to inherit and activate rural traditional culture, look upon folk belief in an objective way and reconstruct public space.

\section{Folk Belief, Public Space and RuRal Cultural ORDER CONSTRUCTION}

Due to the political structure feature of "the same structure of the clan and country" and traditional "loyalty and filial piety" Confucians rite culture in Chinese traditional society,[1] public space is formed with clan regulations, clan disciplines and teachings of the deceased as its main standard, clan rite order under family cultural identity consciousness as its guidance and ancestral halls and family temples as its main carrier. In rural society of this period, autonomous organization is well developed. Ancestral halls and family temples are not only the place for ethics and morality education, but also the material carrier of weddings, birth, promotion and other public cultural activities. Besides ancestral halls, memorial archways, shelter bridges and other landmark structures of this kind, some public space, like big trees and ancient wells, has its own set of etiquette and art of composition to follow, playing an important role in villagers' daily life, regulating rural social order and cultural habits, carrying rural collective cultural memory and becoming the center of public cultural life. In general, at that time, folk belief is the center of rural culture, belief space is the main material carrier of villagers' public cultural life, enriching villagers' spiritual need, bringing entertainment to them, limiting their behavior and making the village a material and spiritual community. During this period, peasants have a strong sense of identity of the village and they are the cultural creators in society, which is regarded as the value and significance of their existence by them. 


\section{EVOLUTION OF CONTEMPORARY RURAL PUBLIC SPACE AND ITS REASON}

\section{A. Spatial Pattern's Morphological Transformation}

Seeing from integral pattern of the village, traditional villages are particular about principles concerning form and context in Fengshui theory: The village with the form of being surrounded by mountains and rivers boasts rosefinch in front, tortoise in the back, green dragon in the left and white tiger in the right; Ancestral halls and temples are in the center of the village or front water and with hills on the back, occupying a place with green hills and clear waters. For example, Banana Bay of Tongshan County in Hubei Province fronts water with hills on the back. Hill represents Yang and water represents Yin. In front there is Flag Mountain with surrounding flowing water. The mountain is on the north and there is also the Kunniu Mountain in the back, forming the situation of "Kunniu looking at the moon". Kunniu refers to the cow. Kunniu Mountain looks like a crouched cow with its body bending and encircling the whole village. Seeing from the layout of village space, Banana Bay belongs to Jiao clan with the cow head showing ancestral grave of Jiao clan and cow eyes showing the grave of Jiao Rong, the ancestor of Banana Bay, with an implied meaning of watching development of Banana Bay.[2] There is a pond with a history of several hundred years in the center of the village. Rumor goes that the pond is used to dominate the Mountain of Flames behind the village. In fact, the pond shoulders the whole village's water storage and drainage function. It can lower the temperature and conserve the water in blistering summer day with a lot of rain, forming an integral ecological system which can conserve water and soil, and provide daily life water for drinking, washing, aquaculture irrigation, farming and flood control. However, in the process of modernization with development of market economy and countryside tourism, villagers gradually neglect this kind of traditional layout in Fengshui theory in site selection of new buildings and tend to choose places with convenient transportation, developed economy or tourism development zone, changing the village's traditional settlement layout, breaking the original natural balanced distribution form's sense of beauty with landscape dependence and leading to the irregular condition of expansion of centralized distributing or sporadic scattered form.

\section{B. Rural Public Space's Functional Transformation}

Based on land ownership of public space, rural public space can be divided into assembly public space, like ancestral halls, temples and drama stages, and public space of daily life, like pond, ancient well and courtyard. Although ancestral halls or temples and other assembly public space with various architectural styles in traditional villages experience changes due to terrain or land limitation, in general, they use nothing more than the traditional axial symmetry and deep layout and obey the traditional etiquette of pecking order and respect for seniority, forming the recognition of collective cultural identity to obtain a cohesive force. Besides these landmark structures, in traditional villages, even a well, a tree or a stone can depend on its special significance to become a public space for villagers to conduct assembly activities, representing a kind of value confirmation and cultural symbol. Ponds and ancient wells are indispensable public space in daily life for traditional villages, where lies the vigor of the village. Many buildings in the village are built along the water, making it convenient for women to wash clothes and vegetables and for children to play and have fun. They are not only the necessary activity space for the village, but also the symbol of "finding water" in the village's Feingshui system. In Book of the Later Han, the micro environmental model outside homestead dreamed by ancient people is "possessing fertile farmland and a mansion fronting water with hills at the back and surrounded by river pools full of bamboos with a field garden in front of the house and an orchard behind it".[3] Besides, giant tress, bleachery or courtyard in front of the house also become the public space for villagers to play, chat, bask in the sunshine, gather to discuss official business and hold weddings and funerals. However, with economic growth, coming of urban material life and culture information makes villagers abandon their original life form and traditional culture and no longer play, chat or conduct activities in traditional public space, breaking the nine-to-five life gradually. In addition, with rural tourism development, some unreasonable development and utilization makes rural pond and stream pollution and wanton felling of trees serious, usage of public space tends to urbanization and square-like, and village life losses its original quietness and simplicity. At the same time, with change of and damage to public space carrying regional cultural features, traditional culture changes and dies, and some traditional architectural forms, festivals and etiquette, local language and folk activities gradually disappear. According to the talk with some villagers of Jiangyuan Village, Tongshan County, Hubei Province in an interview, many local young people are not clear about or even never hear of clan hall, local opera and even customs in the village.

\section{PRACTICAL PATH OF FOLK BELIEF INHERITANCE AND PUBLIC SPACE RECONSTRUCTION}

We can see the mutual correlation between public space, rural culture and social order in modern transformation of rural public space. In modern historical circumstance, how to look upon traditional culture in an objective way and reconstruct public space is of prime importance to preserve and carry forward excellent rural traditional culture and show new vigor in the modernization process and in new rural construction.

Every objective thing is in motion and variation, so does traditional culture. Under the influence of the era, traditional culture constantly changes in its inheritance process and its changes are shown in the public space carried by it. Therefore, in new rural construction, reconstruction of public space should preserve and carry forward regional cultural features contained in traditional villages' public space and experience proper adjustments according to modern culture to preserve and carry forward traditional local features and create a way for villagers to yearn for and pursue modern life.[4] Preserving traditional culture is not getting back to the past and hindering modern people's life style, but an effect inheritance based on respect for tradition. Reconstruction of public space is not simple copying of traditional village buildings and its public space layout and form or artificial copying of this kind of static 
space, but combination of proper extraction of public space's cultural connotation and modernity.

\section{A. Creating Public Space with Regional Culture Features and $a$ Sense of Belonging}

Generation of regional culture is closely related to regional environment and daily life. In China, there are different folk beliefs in different places and diversified belief is a high quality carrier of regional culture with various features. With the help of local belief, regional culture is formed and embodied in public space. Different regional culture relates to different villagers. Villagers work from sunrise to sundown, reproduce and live here from generation to generation, inheriting and deriving different folk beliefs and culture. Under the background of modernization, young villagers become migrant workers who live in the city and recall their "hometown" with emotion derived from local customs and local life of their childhood. In its inheriting process, traditional folk belief changes from carrying faith power in rites of traditional society to formalization of rite. Public space carrying belief culture also losses its original emotional color and connotation expression. For example, sacrifice space is gradually turned into other functional space in the village. Public space preserving folk belief culture is also formalized gradually. Burning joss sticks and kowtow also only exist in form. Construction of this kind of sacrificial culture space emphasizes behavior oriented needs and neglects deep connotation expression of traditional ritual space. Therefore, it is necessary for demotic emotional appeal and belonging to preserve and inherit new rural public space with regional cultural features in modern new rural construction. Constitutional elements of this kind of space are belief rituals and folk cultural activities held in regular places and regular time on the premise of in-depth analysis on humanistic significance and emotional expression of belief culture, rather than simple copying and totally emotionless drill.

\section{B. Symbolic and Metaphoric Quotation of Traditional Culture and Totem}

With invasion of modern urban thought and change of villagers' life style, some traditional culture gradually degrades and disappears in the process of inheriting. Traditional residential form and public space can no longer adapt to modern villagers' actual living requirements. Dismantling old buildings and building new buildings upsurge. Cement box building of European style is popular. Ancestral halls, ancient wells and other public space are at an idle state, making new rural construction apart with previous traditional custom and regional culture. This kind of damage is multifaceted, including traditional rural architectural space environment and rural social structure and intangible culture relics behind it. As a consequence, the basic soil of Chinese traditional culture breeding and inheritance is destroyed and degradation and dying of traditional and regional culture is accelerated. Therefore, in new rural construction, we should protect and inherit regional culture, consider modern peasants' life needs, extract elements of traditional villages' material space carrying belief culture, use metaphoric and symbolic technique and combine with life concept demanded by modern new countryside, modern life style and features of the times to conduct design of public space. New countryside's public space with modernity is more than a kind of visual image with formality beauty, and it should carry the cultural significance carried by traditional rural public space. Environment is no longer a pure space, but a space with multifaceted cultural significance to emphasize public space's "additive attribute" and express a certain meaning.

\section{Diversified Public Space}

Folk belief originates from villagers and definitely serves the life of villagers. When we analyze reasons why folk belief culture should exist and continue from the perspective of modern practicability, we find that as long as folk belief is useful in people's life spiritually or materially, it has a great possibility of cultural continuity and such culture space appears in a diversified form and enriches modern rural public space. Take temple fair inherited in nowadays as an example, it constantly evolves in its historical development process and evolves from the single sacrifice to an integrated activity of sacrifice, entertainment and business. We can see clearly from it that as long as villagers' spiritual and material needs can be met, folk belief culture can be inherited effectively and such public space can still exist in modern countryside. If the socalled service loses its original features and lacks innovations, it definitely is damage to previous life. In addition, in modern society, derivative activities or rituals of folk belief can be enhanced to folk art by exploring its aesthetic factors to conduct artistic creation and transmission.

\section{CONCLUSION}

Folk belief is formed through long-term wide social practice in a certain regional environment. It is rooted in peasants' words and deeds in daily life from generation to generation and embodied in public space, influencing cultural transmission and order establishment of rural society in many aspects. Under the background of new rural construction, we should look upon folk belief in an objective way, positively sublate based on historical experience and the scientific and rational attitude and extract and carry forward loyal, brave and filial piety spirit in folk belief to make it the common spiritual and cultural value of villagers. Derivative folk cultural activities of inheritance of folk belief intensify villagers' memory about and imagination of public cultural life and groupment, expand their social network and deepen rural social interpersonal communication, thus effectively activating rural public space. At the same time, restoration and reconstruction of rural public space is to the benefit of inheritance and holding of folk belief ritual activities. Rural public space becomes the platform for exchange and display of rural cultural activities, reflecting regional natural and humanistic features and forming the new countryside with regional features.

\section{REFERENCES}

[1] Peng Fei. "Combination of Loyalty and Filial Piety" in Socialism Transformation Period[J]. Reporter Monthly, 2008(3).

[2] Ye Yun. Research on Traditional Residential Settlement Ecological Culture in Southeast Hubei Province-- Take Banana Bay, Chuangwang 
Town, Tongshan County, Hubei Province as An Example[J]. SouthCentral University For Nationalities Journal(Humanistic and Social Science Edition), 2009, (04):37-40.

[3] [Song of the Southern Dynasty]Fan Ye. Book of the Later Han[M]. Beijing: Unity Press, 1996.467.

[4] Ma Zhiyao. Paradox and Solution in Intangible Cultural Inheritage Protection[J]. Shandong Social Science, 2010(3):28-33. 